\title{
Translation of Irony in the Hungarian Subtitles of Downton Abbey
}

\author{
Zsuzsanna AJTONY \\ Department of Humanities \\ Sapientia Hungarian University of Transylvania (Miercurea Ciuc, Romania) \\ ajtonyzsuzsa@yahoo.com
}

\begin{abstract}
This paper proposes to analyse ironic utterances in the British TV series Downton Abbey (Season One) by comparing the English source text (ST) irony found in the script of the film to its subtitled variant of the Hungarian target text (TT). First the literature of the domain is surveyed in order to draw attention to the difficulty of rendering irony in audiovisual subtitles which emphasises that, as a multidisciplinary area, it involves not only audio and visual, but also verbal and non-verbal factors. This section is followed by a brief survey of irony theories highlighting the incongruence factor of irony, which also needs to be rendered in the TT. After offering an outline of the story, several examples of ironic utterances are discussed, applying the dynamic equivalence method.
\end{abstract}

Keywords: audiovisual translation, irony, English, Hungarian

\section{Introduction}

Linguistic relativity (the Sapir-Whorf hypothesis) claims that each language reflects a separate social reality. This reality is therefore different from the one reflected in/by another language. Different languages reflect social reality in different ways. As a result,

translation is not simply a matter of substituting words of one language with those of another and adapting the syntax to suit it. For a translation to be successful, the translator has also to convey a whole store of added meaning belonging to the culture of the original language. (Chiaro 1992: 77)

This is especially true in the case of translating irony. Scholars have underlined the particular difficulty in translating ironic statements (cf. Chiaro 1992, Chiaro 2010, Zabalbeascoa Terran 2003, De Wilde 2010). Understanding 
irony first involves its interpretation, i.e. the proper identification of the ironist's intention. From a pragmatic point of view, this means the identification of the illocutionary force of the predication in the SL (what the ironist means by saying something). This illocutionary force will then be transposed into the TL, rendering the necessary linguistic means to convey this message. In the case of a successful translation, the implied ironic meaning will be equivalent with the ironic meaning inferred by the translator and, as a result, by the audience. As Chiaro (1992: 92) claims, "any translation is by its very nature an interpretation of the source text rather than its perfect reflection." Translating irony is exactly the case in point.

Moreover, in interlingual screen translation (as is the case of Downton Abbey) the process of intercultural transfer must also be taken into account. The case of English-Hungarian screen translation especially raises interest if one considers that irony and humour are key features of Englishness. Receivers of the screen translation (readers of the Hungarian subtitles) might not fully understand it in a similar way as the script writer intended it, especially if culture-specific elements also appear in the ST.

Audiovisual translation (AVT) is an area of translation studies with a hybrid and multidisciplinary nature. AV humour and irony are the products of the interdependence of both visual and verbal elements (Veiga 2009a, 2009b). When comparing the spoken word or the script of an audiovisual product (a film, in our case) with its subtitles, Chaume's integrated model of analysis will be considered. This model combines translation studies and film studies (Chaume 2004: 13, 16, quoted in Munday 2008: 188). Chaume enlists ten codes, out of which the linguistic code proves to be relevant for our comparison of ironic utterances both in the source and target languages. He claims that "features of the linguistic code in audiovisual texts are that they are most often scripted, but 'written to be spoken as if not written' which poses considerable demands on the translator to conform to a similar register." (ibid.)

When analysing translated irony in AVT, one needs to consider that in order to successfully render the ironic meaning as properly as possible in the TL, both the translator and the audience are faced with the mixture of verbal and nonverbal (audiovisual) communication. Zabalbeascoa Terran's research (2003: 309) shows that an AV text has four components, each of which contributes to the constitution of the final meaning, of the final effect: both audio and visual, but also verbal and non-verbal elements. 
Table 1. The 4 components of the audiovisual (AV) text (cf. Zabalbeascoa Terran 2003: 309)

\begin{tabular}{|c|c|c|}
\multirow{4}{*}{ Verbal } & \multicolumn{1}{c}{ Audio } & Visual \\
\cline { 2 - 3 } Non-verbal & $\begin{array}{c}\text { Words } \\
\text { heard }\end{array}$ & $\begin{array}{c}\text { Words } \\
\text { read }\end{array}$ \\
\cline { 2 - 3 } & $\begin{array}{c}\text { Music }+ \\
\text { special effects }\end{array}$ & $\begin{array}{c}\text { Picture, } \\
\text { photography }\end{array}$ \\
\cline { 2 - 3 } & &
\end{tabular}

When evaluating the translation of irony in Downton Abbey, three of these components will be taken into account: the words heard (the original English soundtrack), the words read (the Hungarian subtitles) and the picture (the film). The viewer is faced with all three elements and the perlocutionary effect of the communicative input results from the combination of these three. The triad of picture-sound-words must complement each other in any screen translation, and this is especially true in the case of irony translations, as in those cases when situational irony is involved, the facial expression of the character adds meaning to the ironic intention and helps the viewer to identify the utterance as ironic.

Naturally, further constraints are added to the difficulties a translator and subtitler might face: not only of linguistic but also of technical nature, that are called space and time constraints. Maximum two lines may be seen on the screen, consisting of around 36 Roman characters, with a duration of around 6 seconds for each caption. Obviously this leads to a necessary reduction of the number of words on the screen. The subtitler must also try to respect aspects of the cinematography (e.g. camera cuts) and match the duration of subtitles to the rhythm of the dialogue (Munday 2008: 185).

\section{Theories of irony}

Several theories of irony have emerged within the literature of the domain, most of which emphasise the contradiction or incongruity element existing between what is said and what is meant, also referring to "defeated expectations" (Zabalbeascoa Terran 2003: 315). It is very important to make a distinction between verbal irony and situational irony. According to Gibbs (1994: 363), "both verbal and situational irony involve a confrontation or juxtaposition of incompatibles, but in verbal irony an individual presents or evokes such a confrontation by his or her utterance(s), whereas situational irony is something that just happens to be noticed as ironic." Both verbal and situational irony employ incongruity in order to distinguish between facts and expectations (saying one thing and meaning another) while keeping in mind the audience's (reader's) awareness of both. While situational irony highlights events that appear as ironic, regardless of the 
speaker's intention, in the case of verbal irony the speaker creates a juxtaposition of incompatible actions or words with a view to conveying an attitude.

Verbal irony is a linguistic phenomenon exploiting the incongruity between reality and expectation, and consequently, unveiling an attitude towards such an incongruity. According to the rhetoric perspective (cf. Corbett 1971: 489, Booth 1975), irony is an antiphrasis, i.e. an utterance expressing the opposite of its literal meaning. It is in fact a semantic inversion between the primary (literal) meaning and the implicated (non-literal) one.

The translation of irony is a very difficult task because the interpretation of irony presupposes a two-stage processing: first, the processing of a meaning of a specific utterance is rejected, and, second, a reinterpretation of the utterance through inferring an implicature is triggered. This view is based on Grice's Cooperation Principle and its maxims. In Grice's view, irony is a case of conversational implicature. By flouting the Maxim of Quality, the speaker implies the opposite of what is said. The ironist says something s/he does not believe to be true although it is not in his/her intention to tell a lie. The intention conveyed by the ironist's implicature urges the hearer to look for an additional meaning. The addressee feels inclined to reject the literal meaning and to subsequently decipher the implied meaning, highly likely to "be some obviously related proposition; the most obviously related proposition is the contradictory of the one he purports to be putting forward" (Grice 1989: 34). In a later study, Grice (1989: 41-58), broadens the definition of irony by incorporating the notion of an attitude into it: "To be ironical is among other things, to pretend (as the etymology suggests), ${ }^{1}$ and while one wants the pretence to be recognized as such, to announce it as pretence would spoil the effect." (ibid. 54) Here, irony is recognised as a verbal resource meant to convey an evaluative position on the part of the speaker.

Later, two post-Gricean attempts have been put forward to provide a rationale for irony. One approach (Sperber and Wilson) treats verbal irony as a type of echoic allusion to an attributed utterance or thought. According to this view, the speaker interprets an earlier thought or utterance and uses an utterance interpretively (cf. Sperber and Wilson's relevance theory 1986). He/She "is expressing her own reaction to a thought or utterance with a similar content which she tacitly attributes to someone else (or to herself at another time), and which she wants to suggest is ludicrously false, inadequate or inappropriate" (Wilson 2006: 1724). The aim of such a reaction is to express a critical or mocking attitude to such a false utterance and it actually dissociates the speaker from this tacitly attributed utterance.

1 The etymology of the word itself means pretence. The word "irony" derives from the Greek eirōneía (cf. also Latin: ironia), which means "simulated ignorance", "the pretence of ignorance". The Greek term eironia describes the main characteristic of the stock characters (the "ironic man") in early Greek comedies. Source: Glottopedia, accessed 10.04.2010. 
The second post-Gricean approach is suggested by the etymology of the word "irony" and treats verbal irony as a type of pretence. According to this approach, the speaker is not asserting but merely pretending to assert a proposition, and expects his/her audience to see through the pretence and recognise the critical or mocking attitude behind it (Wilson 2006: 1725, further developed by Clark and Gerrig 2007).

\section{Downton Abbey - a brief outline of the story}

The story revealed by the film (and the script) is based on the life and concerns of the English aristocratic Crawley family and their servants living in the Edwardian mansion called Downton Abbey. Robert Crawley, the Earl of Grantham, "custodian" of Downton, soon learns that he lost his heirs in the tragedy of the Titanic (we are in 1912). A distant cousin, Matthew Crawley, a Manchester lawyer, is the next to inherit his property. Matthew moves to Downton together with his mother, Isobel Crawley, who has quite modernist and feminist views. This is enough reason to clash with the Dowager Countess, Robert's mother, Lady Violet, a conservative and domineering elderly woman. Another concern of the Crawleys, Robert and his American wife, Cora, is to marry their three daughters, Mary, Edith and Sybil. Robert considers his outmost duty to preserve Downton the way it is but the social and historical changes (the WWI, the ever stronger emergence of women's emancipation, etc.) bring several obstacles to carry out this noble plan. The "under the stairs" group of characters - the staff - living in the servants' quarters also have their more tradition-bound vs. more liberal representatives, with Charles Carson, the butler, as the head of the servants' social ladder, who watches that good manners and respectability are preserved on both levels of the house and who also supervises the work of different male servants (the valets, first and second footmen and the chauffeur), Mrs Hughes, the housekeeper and head of the maids of different rank and status, Mrs Patmore, the cook of the house together with her aid, Daisy, the lowest in rank in the house.

\section{Comparative analysis of script and subtitles in Downton Abbey}

Analysing the interlingual translation of Downton Abbey may be of interest for several reasons. Firstly, because of the high frequency of references to culturespecific elements in the ST, which makes this series so English. Secondly, as it is irony and humour (typical English humour) that is a stereotypical, recurrent and pervasive feature of British culture and proves to be great challenge even for the 
competent translator. This paper proposes to discuss both of these characteristics, by comparing several examples of irony and socio-cultural specificities in the original script and the Hungarian subtitles. I am dealing with them together as ironic utterances frequently make allusions to social and cultural references which must be rendered in the target language in a proper way so that the foreign language viewer can make similar inferences and can understand irony more or less similarly as the English-speaking audience who are socialised within this socio-cultural background. This is underlined by Chiaro as well, when she claims that "when sociocultural constraints are combined with linguistic restraints, translating becomes an arduous task" (Chiaro 1992: 84).

In this paper a dynamic pragmatic approach to irony is followed (see De Wilde 2010). This methodological approach functions on the basis of the descriptive paradigm, i.e. it takes "the existing and empirically observable texts as the starting point for the analysis, without having previously adopted fixed criteria and minimum conditions according to which a given text is considered a translation of another text” (De Wilde 2010: 29, my emphasis). On the other hand, as a comparison is carried out between ST and TT, the comparative procedure involves looking at similarities and differences between two different entities, two texts in two languages (ibid. 30).

As translating irony is a special kind of task, which - to a certain degree - is untranslatable (partially due to its linguistic and socio-cultural rootedness), in the process of interpretation, when comparing the ST and TT irony, the 'invariant core' (Popovič 1976) has to be found, while the 'formal' equivalence will be sacrificed for the 'dynamic' equivalence (Nida 1964, quoted in Chiaro 1992: 92). This is the case of the first example from Downton Abbey, in which Mrs Hughes, the housekeeper criticises Daisy, the kitchen maid, for being too slow in her regular work of lighting the fire.

\begin{tabular}{ll}
\hline \multicolumn{1}{c}{ Original English text } & \multicolumn{1}{c}{$\begin{array}{c}\text { Hungarian translated/subtitled } \\
\text { version }\end{array}$} \\
\hline $\begin{array}{l}\text { MRS HUGHES Oh, heavens, girl! } \\
\text { You're building a fire, not inventing it. } \\
\text { (Episode 1, Act One) }\end{array}$ & $\begin{array}{l}\text { MRS HUGHES Az égre, te lány! Tüzet } \\
\text { [Oh, he máglyát! } \\
\text { bonfire!] }\end{array}$ \\
\hline
\end{tabular}

In both the ST and the TT the main aim of the speaker is to scold her interlocutor for her slow work. In the ST she employs an indicative phrase in the present continuous referring to the tedious work of fire building. She implies that inventing the fire in man's history took much longer than building one in the fireplace. The Hungarian text is based on imperative sentences, but this historical reference is missing; it is replaced by a textual reference to a much larger type of 
fire (a bonfire) which obviously takes much longer to build. So while the syntactic and morphologic structure was changed, the semantic core of the ST has been retained in the TT.

A similar ironic utterance appears in the following example where the servants discuss the arrival of the Crawleys' new relative, who might become the new heir to the estate.

\begin{tabular}{ll}
\hline $\begin{array}{l}\text { WILLIAM Are we to treat him as the } \\
\text { heir? }\end{array}$ & $\begin{array}{l}\text { WILLIAM Aztán örökösként bánjunk } \\
\text { vele? }\end{array}$ \\
MISS O’BRIEN Are we heck as like. & [Then should we treat him as an heir?] \\
A doctor's son from Manchester? & MISS O’BRIEN Még csak az kéne! Egy \\
Humph. He'll be lucky if he gets a & manchesteri ügyvéddel? Örülhet, ha \\
civil word out of me. & egy normális szóra fogom méltatni. \\
ANNA We're all lucky if we get a civil & [You just wish! A lawyer from \\
word out of you. & Manchester? He may be happy if I \\
(Episode 2, Act One) & speak normally to him.] \\
& ANNA Mi is örülnénk a szép szónak \\
& magától \\
& [We would also be happy to get some \\
& nice words from you.] \\
\hline
\end{tabular}

Miss O'Brien's irony is targeted towards the possible heir as she despises the newcomer who does not belong to the aristocracy, like her master and mistress; he is just an upper-middle class lawyer coming from an industrial city. Therefore, in her view, he is not a respectable gentleman. The saying "are we heck as like" is not translated literally, but its meaning is retained (see the meaning of 'the heck' as 'azt már nem!'; 'nehogy már!'; 'toll a füledbe!' in Kövecses 2005: 208). 'A doctor's son from Manchester!' (31 characters) is shortened because of space and time constraints. In the Hungarian subtitle ('Egy manchesteri ügyvéddel?') the father's job is left out (25 characters); instead the job of the heir is mentioned (lawyer) and the city's name. Both are civil jobs, not aristocratic pastimes, so the basic idea is maintained. The question is whether the toponym 'Manchester', as a busy industrial city, has the same connotations for the Hungarian viewers as for those from the Anglo-Saxon culture. Further on, the interjection 'humph' is omitted, as it is heard in the soundtrack, while the facial expression of the character also adds to her attitude of despise and displeasure. The English version of the next sentence contains an indicative in the future form, while its Hungarian variant contains a conditional, which might suggest that while in English the speaker takes the heir as an unavoidable reality, the Hungarian version still considers him as a possibility. This sentence forms the starting point for the next character's ironic utterance, which, as an interference into the 
two earlier speakers' conversation, is targeted against the former speaker, Miss O'Brien. The Hungarian translation continues the use of the conditional mood, while the English utterance contains an indicative.

Mrs Patmore, the cook is one of those women in the story who - as a woman in power (in the kitchen) - frequently employs irony which aims at mocking those in her subordination. So she often criticizes Daisy, the formerly mentioned kitchen maid, for different reasons. For instance, in the following examples, she uses irony with an evaluative edge because Daisy fails to instantly obey her orders:

MRS PATMORE Daisy, did you hear me call, or have you gone selectively deaf?!

DAISY No, Mrs Patmore.

MRS PATMORE Then might I remind you we are preparing dinner for your future employer, and if it goes wrong, I'll be telling them why!

(Episode 2, Act One)
MRS PATMORE Daisy, nem hallottad, hogy hívtalak, vagy netán szelektív a hallásod?

[Daisy, haven't you heard me call you or perhaps you've got selective hearing?]

DAISY Nem, Mrs Patmore.

[No, Mrs Patmore.]

MRS PATMORE Akkor emlékeztethetlek arra, hogy a leendő munkáltatónknak készítjük a vacsorát? És, ha nem sikerül, elmondom nekik az okát!

[Then might I remind you that we are peparing dinner for our future employer? And if it goes wrong, I'll tell them the reason.]

In both sides of the question of the English text the speaker uses an interrogative, while in the Hungarian version this has been changed into a negative interrogative. On the other hand, the term "go + adjective" suggests a process which the Hungarian translation renders in the form of a state ("you are selectively deaf'). The irony continues in the following turn as well where the cook gives the reason why she urges the maid to follow her orders. While in the English version the $1^{\text {st }}$ person plural 'we' is combined with $2^{\text {nd }}$ person singular 'your', more emphatically putting the blame on Daisy for the possible lack of success, the Hungarian text keeps the $1^{\text {st }}$ person plural personal pronoun markers all through the utterance, which suggests sharing the blame with the interlocutor (inclusive 'we', which includes the speaker as well). It must also be added that while the English text contains one single complex sentence which connects the subordinate clauses with the coordinative conjunction 'and', the Hungarian version starts a new sentence with 'and', thus trying to render the dynamics of oral speech. 
Similar examples can be further enlisted: happened to you? I said you could go for a drink of water, not a trip up the Nile.

(Episode 3, Act One)
MRS PATMORE Daisy! What's

MRS PATMORE Daisy! Mi történt veled? Aszontam, elmehetsz vizet inni, nem pedig egy núlusi körútra.

[Daisy, what's happened to you? I said you could go for a drink of water, not a cruise on the Nile.]

DAISY Do these biscuits go up? DAISY Ezek a kekszek is felmennek? MRS PATMORE No, I put them out for the fairies.

DAISY Oh.

MRS PATMORE Of course they're going up. What's wrong with you? You're always dozy, but tonight you'd make Sleeping Beauty look alert. (Episode 6, Act Three)
[Do these biscuits go up?]

MRS PATMORE Nem, félretettem a jótündéreknek.

[No, I put them away for the good fairies.]

Persze, hogy felmennek! Mi bajod van? Folyton álmos vagy, de ma este kész Csipkerózsika lettél!

[Of course, they go up! What's the matter with you? You are always sleepy, but tonight you've become a real Sleeping Beauty.]

In both examples there are some socio-cultural references which the ironic utterance relies on. In the first case, 'a trip up the Nile' has a typical British cultural background, the British aristocracy often travelling for pleasure in their colony in Egypt (let us not forget that the plot of Downton Abbey takes place in the first decade of the $20^{\text {th }}$ century, when Britain was still at the height of its power). The cultural connotation might be missing for the Hungarian viewers.

The second example also contains a reference to a fairy tale (Sleeping Beauty) which is so well known in other European cultures as well that its interpretation does not cause any difficulty to the Hungarian viewers either. However, while the Hungarian version contains direct criticism at Daisy's expense ('tonight you have become a regular Sleeping Beauty'), the English text is more indirect in this respect, containing a hyperbole, so typical for ironical language use. The phrase 'make sy look alert' implies that the person under scrutiny (in this case, Daisy) surpasses the Sleeping Beauty state by being more dozy than the fairy tale character.

Nevertheless, the Hungarian subtitles of Downton Abbey also contain examples where the translator is in a much more difficult position, i.e. where the irony lies on verbal play that can be interpreted properly only by the English audience. This is the case of the following exchange where Lady Sybil, the youngest of the Crawley daughters, expresses her intention to take active part in the elections by helping the candidates get more political support. Obviously the elder family 
members, especially the grandmother, the dowager countess, do not approve of this, so they express their dissatisfaction about it in an ironical tone.

\begin{tabular}{|c|c|}
\hline $\begin{array}{l}\text { LADY SYBIL I want to do some } \\
\text { canvassing. The by-election isn't far } \\
\text { off. } \\
\text { [Robert and Violet stare open mouthed } \\
\text { at Sybil.] } \\
\text { VIOLET, DOWAGER COUNTESS OF } \\
\text { GRANTHAM Canvassing? } \\
\text { LADY SYBIL Oh, it's quite safe. You're } \\
\text { in a group and you knock on doors. } \\
\text { VIOLET, DOWAGER COUNTESS } \\
\text { OF GRANTHAM Yes, I know what } \\
\text { canvassing is. } \\
\text { LADY MARY I think that Sybil is- } \\
\text { VIOLET, DOWAGER COUNTESS } \\
\text { OF GRANTHAM What? Are you } \\
\text { canvassing, too? Or would you rather } \\
\text { take in washing? } \\
\text { (Episode 6, Act One) }\end{array}$ & $\begin{array}{l}\text { LADY SYBIL Ó, az elég biztonságos. } \\
\text { Csoportosan járjuk a házakat. } \\
\text { [Oh, that's quite safe. We go to houses } \\
\text { in groups.] } \\
\text { VIOLET Tudom jól, mit jelent a } \\
\text { korteskedés. } \\
\text { [I know very well what canvassing } \\
\text { means.] } \\
\text { LADY MARY Szerintem Sybil... } \\
\text { [In my opinion, Sybil ...] } \\
\text { VIOLET Miaz? Netán te is korteskednél? } \\
\text { Vagy inkább mosnál? } \\
\text { [What is it? You would like to do some } \\
\text { canvassing, too? Or would you rather } \\
\text { do some washing?] }\end{array}$ \\
\hline
\end{tabular}

In this case, the irony is based on the different meanings and interpretation of the word 'canvassing'. While Sybil and Mary use the term in its political sense, i.e. 'to go around the area asking people for political support', Lady Violet (intentionally or unintentionally?) employs the term in its other, related meaning, i.e. 'to peddle, to hawk, to offer one's services by knocking on other people's doors'. Moreover, there is a semantic relation between the words 'canvas' (a type of cloth) and 'washing'. The English text exploits the homographic use of the term to the maximum, but obviously, for linguistic reasons, the Hungarian version does not (cannot) contain a similar verbal play, therefore the Hungarian viewers will probably not understand the presence of the phrase 'Vagy inkább mosnál?' ('Or you'd rather wash?') as it is not relevant to the previous context at all.

Another instance of a socio-cultural item present in the ST is the ironic mention of Guy Fawkes, who is notorious historical figure from the early $17^{\text {th }}$ century, famous for the Gunpowder Plot (1605). 


\begin{tabular}{ll}
\hline WILLIAM There they go, Guy Fawkes & WILLIAM Ott mennek... A cselszövő \\
and his assistant. & és a szárnysegédje. \\
GWEN Which is which? & [There they are going... The schemer \\
(Episode 7, Act One) & and his adjutant.] \\
& GWEN Melyik melyik? \\
& [Which is which?] \\
\hline
\end{tabular}

As in Downton Abbey there are two characters who keep conspiring against other servants, the reference is clear. However, the Hungarian audience might not be familiar with the historical background of the $17^{\text {th }}$ century event, therefore what the TT mentions is not Guy Fawkes' name, as a historical realia, but "the invariant core”, the common noun 'cselszövő' ['schemer', 'shifter'], which makes the reference more explicit. Moreover, a similarly strong historical and cultural connotation of the term 'cselszövô' might be mentioned in Hungarian, the source of which is a famous line from the Hungarian composer, Ferenc Erkel's wellknown opera, Hunyadi László: 'Meghalt a cselszövő, nem dúl a rút viszály' [The schemer is dead, there's no more ugly hostility ${ }^{2}$.

Idioms or proverbs typical to English may cause difficulty for the audiovisual translator, mainly if they are mingled with ironic utterances. One such instance can be found in the following exchange, where the Hungarian variant cannot render the strangely ironical stance of the idiom 'as dead as a doornail'.

\begin{tabular}{ll}
\hline MR CARSON (...) He was a handsome & MR CARSON (...) Egyik pillanatban \\
stranger from foreign parts one & itt van egy jóképü külföldi, a \\
minute, and the next he was as dead & következőben meg meghal. Ez \\
as a doornail. It's bound to be a & óhatatlanul sokkoló. \\
shock. & [One moment we have this handsome \\
(Episode 3, Act Three) & foreigner, the other moment he dies. \\
& This is inevitably shocking.] \\
\hline
\end{tabular}

Similarly, another proverb appears in Robert Crawley's utterance which - quite stereotypically - refers to the way one needs to act when far from home.

\begin{tabular}{ll}
\hline CORA, COUNTESS OF GRANTHAM & CORA, COUNTESS OF GRANTHAM \\
Don't listen when His Lordship & El ne higgye, hiszen őlordsága nagyon \\
pretends not to enjoy the Season. & is élvezte a szezont! \\
ROBERT, EARL OF GRANTHAM & [Don't believe it, His Lordship was \\
When in Rome. & really enjoying the season.] \\
(Episode 7, Act One) & ROBERT, EARL OF GRANTHAM \\
& Mikor Rómában... \\
& [When in Rome...] \\
\hline
\end{tabular}


There is just a reference to the proverb 'When in Rome, do as the Romans do'. The English ST contains only the beginning of the proverb, which - as it is frequently used in English - is well-understood by the receivers. The same shortened version appears in the Hungarian translation ('Mikor Rómában...'), but for the Hungarian viewers this does not make sense as the proverb is non-existent in the TL.

Finally, there are cases when the conscious viewer can detect Hungarian translations which do not always render the English text properly, i.e. the TT does make reference to the ST but it drives the meaning in an utterly new direction.

\begin{tabular}{ll}
\hline ROBERT, EARL OF GRANTHAM (...) & ROBERT, EARL OF GRANTHAM (...) \\
If it had been left to that bloody fool, & Ha arra a véres szájú bolond Bransonra \\
Branson. & maradt volna... \\
(Episode 6, Act Four) & $\begin{array}{l}\text { [f it had been left to that bloody- } \\
\text { mouthed Branson...] }\end{array}$ \\
\hline
\end{tabular}

The phrase 'that bloody fool' seems to have been translated into Hungarian as 'blood-mouthed fool'. While the ST employs an informal use of a judgement or comment, meaning 'extremely' or 'absolutely', the Hungarian text uses the same word in a figurative sense, 'véres szájú' referring to somebody who talks in a way that stirs anger, full of passion, instigating (see MÉK 1992). It seems that the translator gives a more explicit description of Branson, the Irish nationalist chauffeur employed by the Crawleys, the Hungarian translation referring to his ethnic and political background.

The last example to be offered is another case of mistranslation. While the English ST makes an indirect, but quite clear reference to a church aisle where the bride and the groom go down without having told everything about their previous affairs to their future spouses, the Hungarian translation speaks of a 'dead end' ('zsákutca') from where there is no way out.

\begin{tabular}{ll}
\hline VIOLET, DOWAGER COUNTESS OF & VIOLET, DOWAGER COUNTESS OF \\
GRANTHAM She reads too many & GRANTHAM Túl sok regényt olvas. Így \\
$\begin{array}{l}\text { novels. I mean, one way or another, } \\
\text { everyone goes down the aisle with }\end{array}$ & $\begin{array}{l}\text { vagy úgy, de mindenki bemegy abba a } \\
\text { half the story hidden. }\end{array}$ \\
$\begin{array}{ll}\text { (Episode 6, Act Four) } & \text { [She reads too many noveligazságokat mond el. } \\
\text { another, but everybody enters the dead- } \\
\text { end of telling half-truths. }\end{array}$ \\
\hline
\end{tabular}




\section{Conclusions}

With the comparison of the English and the Hungarian variants of ironic statements in Downton Abbey I tried to prove that the translator needs to be both competent and creative, possessing not only linguistic, but also socio-cultural and technical competence. The success of an English language television series in non-Englishspeaking countries depends to a great extent on its successful subtitling. It is the translator's task to achieve a good quality translation by paying attention not only to the verbal rendering of the source text into the target language, but also to conveying the more indirect, ironic, and therefore, ambiguous utterances as well. This is especially important in the case of a series like Downton Abbey, because irony is one of the most defining, stereotypical features of the English culture that this series aims to transmit to its target audience.

\section{References}

\section{Audiovisual reference:}

Downton Abbey, Season 1 (creator Julian Fellowes, 2010, UK)

\section{References:}

Booth, Wayne C. 1975. A Rhetoric of Irony. London/New York: The University of Chicago Press.

Chiaro, Delia. 1992. The Language of Jokes. Analysing Verbal Play. London: Routledge.

Chiaro, Delia (ed.). 2010. Translation, Humour and the Media: Translation and Humour. London: Continuum.

Clark, Herbert H. and Gerrig, Richard J. 2007. On the Pretense Theory of Irony. In R. Gibbs, H.L. Colston (eds.), Irony in Language and Thought: A Cognitive Science Reader, 25-33. New York: Lawrence Erlbaum Associates.

Corbett, Edward. 1971. Classical Rhetoric for the Modern Student. New York: Oxford University Press.

De Wilde, July. 2010. The analysis of translated literary irony: Some methodological issues. In Lievois, Katrien and Pierre Schoentjes (eds.), Translating Irony. Linguistics Antverpiensia: Themes in Translation Studies, 25-44. Asp / Vubpress / Upa.

https://lans-tts.uantwerpen.be/index.php/LANS-TTS/article/view/260/162. Retrieved 12 March, 2014. 
Gibbs, Raymond. 1994. The Poetics of Mind: Figurative Thought, Language, and Understanding. New York: Cambridge University Press.

Grice, Paul. 1989. Further Notes on Logic and Conversation. In: Grice, P. (ed.), Studies in the Way of Words, 41-57. Cambridge, Mass.: Harvard University Press. Kövecses, Zoltán. 2005. Angol-magyar kifejezéstár. Budapest: Magyar Könyvklub. Juhász, József et. al. (eds.). 1992. Magyar Értelmezó Kéziszótár (MÉK). Budapest: Akadémiai.

Munday, Jeremy. 2008. Introducing Translation Studies - Theories and Applications. $2^{\text {nd }}$ edition. London and New York: Routledge.

Popovič, Anton. 1976. Dictionary for the Analysis of Literary Translation. Edmonton, Alberta: Department of Comparative Literature. University of Alberta.

Sperber, Dan and Wilson, Deidre. 1986. Relevance: Communication and Cognition. Oxford: Blackwell.

Veiga, José Maria. 2009a. Linguistic Mechanisms of Humor Subtitling. Oral Presentation. New University of Lisbon: Portugal. www.clunl.edu.pt/.../ linguistic\%20mechanisms\%20of\%2... Retrieved 12 March 2014.

Veiga, José Maria. 2009b. The Translation of Audiovisual Humour in Just a Few Words. In Díaz Cintas, Jorge (ed.), New Trends in Audiovisual Translation, 158-175. Briston, Buffalo, Toronto: Multilingual Matters.

Wilson, Deidre. 2006. The Pragmatics of Verbal Irony: Echo or Pretense? Lingua 116: $1722-1743$.

Zabalbeascoa Terran, Patrick. 2003. Translating Audiovisual Screen Irony. In: Luis Perz Gonzales (ed.), Speaking Tongues: Languages across Contexts and Users, 305-322. Edicions Universitat de Valencia. 